\title{
Leaf Spot of Nymphoides peltata Caused by Septoria villarsiae in Korea
}

\author{
Mi-Jeong Park ${ }^{1}$, Ji-Hyun Park ${ }^{1}$, Young Dae Kwon ${ }^{2}$ and Hyeon-Dong Shin ${ }^{1 *}$ \\ ${ }^{1}$ Division of Environmental Science and Ecological Engineering, Korea University, Seoul 136-701, Korea \\ ${ }^{2}$ Team of Tree Research, Gyeonggi-do Forestry Environment Research Center, Osan 447-290, Korea \\ (Received on February 16, 2010; Accepted on March 8, 2010)
}

Nymphoides peltata (syn. Limnanthemum nymphoides, Villarsia nymphaeoides) is an aquatic flowering plant in the family Menyanthaceae, and commonly called fringed water-lily or water fringe. The plants are widely cultivated for ornamental purposes in ponds and water gardens in Korea. In June 2008, plants showing typical symptoms of leaf spots with yellowing were first found in a pond in Osan, Korea. Simple microscopic examination suggests that the spots are associated with infections by a species of Septoria (Shin and Sameva, 2004). Further surveys of water gardens in Korea were made in 2008 and 2009, and we confirmed the occurrence of the disease in Daejeon, Incheon, Pocheon, Pyeongchang and Suwon.

The leaf spots frequently occurred, detracting from the beauty of glossy leaves of the plant (Fig. 1A). Under certain circumstances, leaves were heavily infected even before they unfold at the water surface, devastating whole host populations. Initial symptoms were circular, pale greenish to brownish, later expanding to form larger lesions without definite margin. Numerous black conidiomata were formed on the surface of the lesion(Fig. 1B). Under humid condition and also by placing the infected leaves in humid chamber, white to cream-colored conidial horns were produced from conidiomata

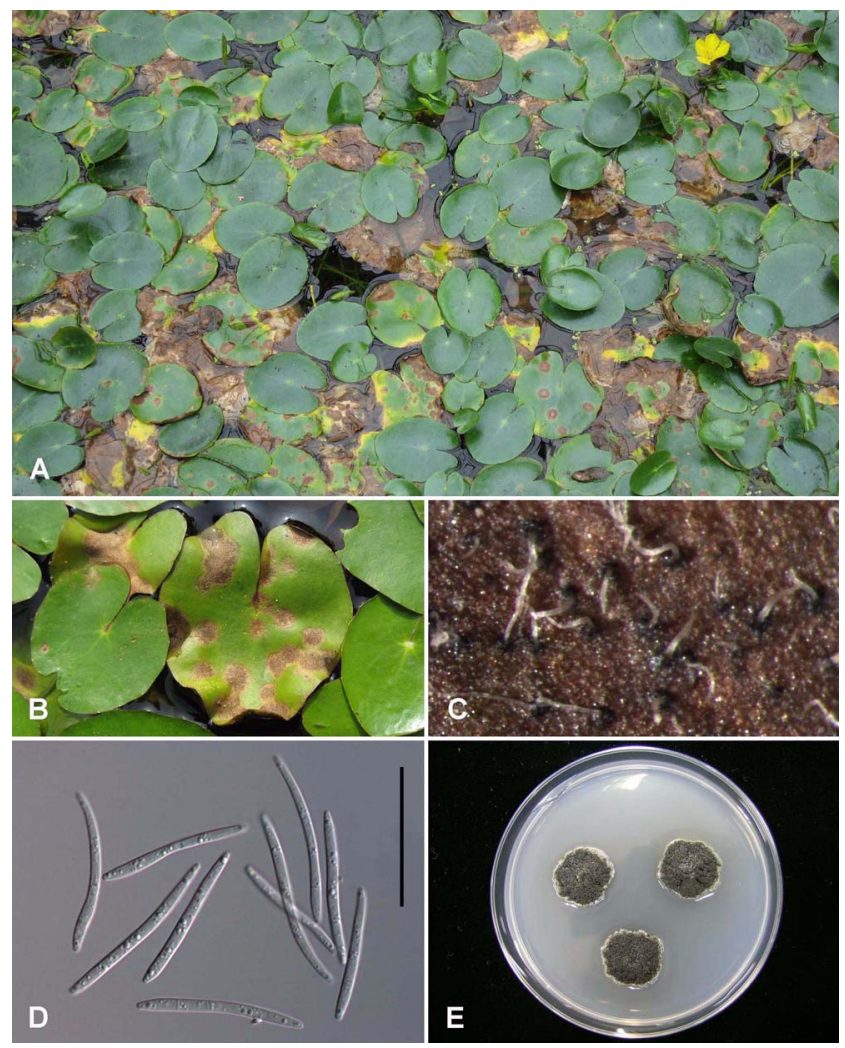

Fig. 1. Leaf spots (A) on the leaves of Nymphoides peltata infected with Septoria villarsiae and a close-up (B) of lesions. Conidiomata with conidial horns (C) and conidia (D) of S. villarsiae $(\mathrm{Bar}=30 \mu \mathrm{m})$. (E) Threeweek-old colony of $S$. villarsiae growing on potato dextrose agar.
(Fig. 1C).

Microscopic examination of the lesions from fresh materials was performed under a microscope. Conidiomata were pycnidial, epiphyllous, scattered to confluent, sometimes 2-3(-5) pycnidia touched with their walls, dark brown to rusty brown, globose, immersed in host tissue or somewhat erumpent, $40-90 \mu \mathrm{m}$ in diameter, with an ostiole of $15-30 \mu \mathrm{m}$ in diameter. Conidia were substraight, guttulate, hyaline, 25-55×2-2.5 $\mu \mathrm{m},(0-) 1-5$-septate (Fig. 1D). Single conidial isolates formed dark greyish colonies on potato dextrose agar (Fig. 1E). Based on the morphological characteristics, the causal fungus was identified as Septoria villarsiae Desm. (Radulescu et al., 1973; Paul and Singh, 2003). Voucher specimens are housed at Korea University (KUS-F23403, F24594) and isolates were deposited in the Korean Agricultural Culture Collection of the National Academy of Agricultural Science (KACC43773, KACC44794).

Conidiomata matured after 5 weeks when plates were incubated under fluorescent illumination for $12 \mathrm{hrs}$ photoperiods at $25^{\circ} \mathrm{C}$, producing abundant conidia. Pathogenicity was confirmed by inoculating the leaves of three plants with a conidial suspension (ca. $2 \times 10^{5}$ conidia $/ \mathrm{ml}$ ). Three non-inoculated plants served as controls. The plants were covered with plastic bags for maintaining $100 \%$ relative humidity for $48 \mathrm{hrs}$. After 8 days, typical leaf blotch symptoms, identical to the ones observed in the field, started to develop on the leaves of inoculated plants. No symptoms were observed on control plants. Septoria villarsiae was reisolated from the lesions of inoculated plants, fulfilling Koch's postulates.

The leaf spot diseases associated with $S$. villarsiae have previously been recorded on $N$. peltata in Romania (Radulescu et al., 1973), the Netherlands (Van der Velde et al., 1982), and India (Paul and Singh, 2003). To our knowledge, this is the first report of this fungus as well as its host plant in East Asia.

\section{Acknowledgement}

This work was financially supported by research grants from the BioGreen 21 program (no. 20080401034028), Rural Development Administration, Korea.

\section{References}

Paul, Y. S. and Singh, A. 2003. Indian Septoriae. Scientific Publishers, Jodpur, India. $89 \mathrm{pp}$.

Radulescu, E., Negru, A. and Docea, E. 1973. Septoriozele din Romania. Bucuresti, Romania: Editura Academiei Republicii Socialiste Romania.

Shin, H. D. and Sameva, E. F. 2004. Septoria in Korea. National Institute of Agricultural Science and Technology, Suwon. 183 pp.

Van der Velde, G., Van der Heijden, L. A., Van Grunsven, P. A. J. and Bexkens, P. M. M. 1982. Initial decomposition of Nymphoides peltata (Gmel.) O. Kentze (Menyanthaceae), as studied by the leaf-marking method. Hydrobiological Bulletin 16:51-60.

*Corresponding author (hdshin@korea.ac.kr) 